\title{
Benelli Mastopeksy Scar Revision Using Vertical Mastopexy Insicion: A Case Report
}

\author{
Mustafa Tercan \\ Plastic and Reconstructive Surgery, School of Health Science, Kirklareli University, Kirklareli, Turkey. \\ Email: mtercan66@yahoo.com
}

Received October $13^{\text {th }}, 2012$; revised November $15^{\text {th }}, 2012$; accepted December $17^{\text {th }}, 2012$

\begin{abstract}
Minimal or moderate breast ptosis can be treated with Benelli mastopexy technique in experienced hands. Tightening of the periareolar tissue, inappropraite suture usage, excessive tissue removal lead to severe complications in some patients. Patients with these complications is more than difficult to treat breast ptosis. It needs extra tissue to reduce the tensions in patients with wide circumareolar scar tissue and wide areolary complex. Vertical scar mastopexy technique can be used to treat these type of complications as a scar reduction methods.
\end{abstract}

Keywords: Scar Revision; Mastopexy; Benelli; Vertical Scar; Mastopexy Complication

\section{Introduction}

Breast lifts are considered to be relatively safe procedures that can improve the appearance of sagging and drooping breasts. Benelli breast lift technique (donut lift), featuring the cutting out of a concentric ring of flesh from around the nipple-areola complex, limits the size and diameter of the circular scar. There are some complications that may occur in this technique. Typically, these complications are minor. However, there can be severe complication especially inexperienced hands. A wide circumareolar scar with wide areola is one of the major complication in Benelli mastopexy. This type of complications can be corrected as much as possible by using vertical scar mastopexy insicions.

\section{Case}

A 36 years old female admited to the Haydarpaşa Numune Research and Trainig Hospital in 2010. She had breast augmentation with $225 \mathrm{cc}$ silicon six years ago. She was complaining her wide periareolar scar tissue due to previous mastopexy operation in 2009. She was in depression psychologically because of unsuccessful breast lift operation.

On physical exam, breast areola on both sides was so wide and there was $2 \mathrm{~cm}$ wide thick scar tissue. Breasts were asymmetric and nipple areolar distance is $20 \mathrm{~cm}$ on left side and $21 \mathrm{~cm}$ on the right side. Both breasts were seen flattened.

\section{Material and Methods}

Under general anesthesia, breast tissue infiltrated with
$1 / 500,000$ epinephrine. Both areolas marked as $4.3 \mathrm{~cm}$ and the whole scar tissue excised. After excision of the scar, the real tissue defect came out. It was impossible to close the defect by using simple stitches. So, skin undermining was performed widely to hinder the scar widening after the operation. After closing the periareolar defect, a bottoming of the skin was seen on the lower part of the breast. Skin was de-epitelized similar to the vertical scar mastopexy method and some fat tissue excised to facilitate the closing of the skin. About 100 gr. scar and fat tissue was removed. Dermal tissue was stitched to the pectoral fascia and the lateral flap of the lower part of the breast was also stitched to the edge of the dermis to reduce the skin tension. This type of the stitching of the flaps prevented of the widening of the periareolar scar again (Figure 1).

\section{Discussion}

Moderate ptosis (Grade II), which can be corrected with a circumareolar Benelli mastopexy technique featuring Benelli cerclage suturing. For the first few months following breast surgery, scars will be very noticeable in some cases. In general, most of these scars will begin to fade over several months. Sometimes, breast lift scars can become undesirable complications if they form abnormally. Keloids, thick and wide, mushroom-shaped scars that extend beyond the incision site, may form due to a rapid healing process. Similar to keloids and raised hypertrophic scars may also form especially in high tension of the periareolar skin. There is also the risk of parts of the breast becoming hard due to abnormal scar 


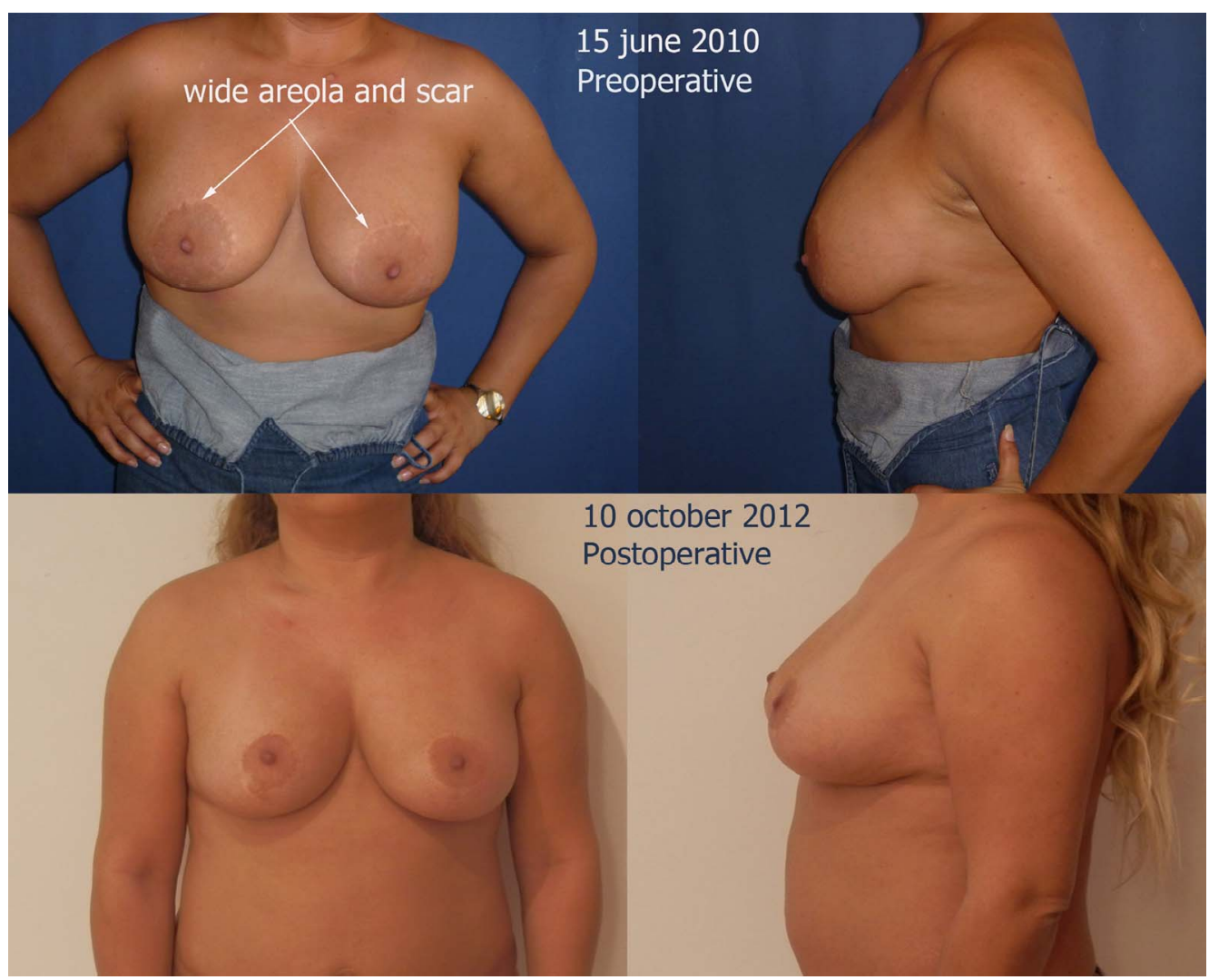

Figure 1. Preoperative and postoperative photos of the patient.

tissue formation. Hematomas can also increase the risk of scar tissue formation, and certain types of infection can lead to the formation of abnormal scars. Inappropriate sutures can increase the this type of complications [1]. In some cases, an additional surgery may be required to improve the appearance of these scars [2]. The use of silicone sheeting may also reduce the risk of scar formation if used during recovery. However in severe case, corrective operation inevitable like in this case. Only excision of the scar could worsen of the problem. Vertical scar mastopexy insicion is a good option to correct these type of complication. Not only can it be revised scars but correct the flattened of the breast. It is no need to make breast size reduction to revize the scar in breast with silicon implant.

\section{Conclusion}

Vertical scar mastopexy insicion is a good and simple option for revision of the Benelli mastopexy scar complication easy. This type of scar revision can correct the flattening of the breast with silicon in addition of the wide scar revision.

\section{REFERENCES}

[1] W. G. Stevens, D. A. Stoker, M. E. Freeman, S. M. Quardt and E. M. Hirsch, "Mastopexy Revisited: A Review of 150 Consecutive Cases for Complication and Revision Rates," Aesthetic Surgery Journal, Vol. 27, No. 2, 2007, pp. 150-154. doi:10.1016/j.asj.2006.12.014

[2] C. N. Baran, F. Pecker, T. Ortak, Ö. Sensöz and N. K. Baran, "Unsatisfactory Results of Periareolar Mastopexy with or without Augmentation, and Reduction Mammoplasty: Enlarged Areola with Flattened Nipple," Aesthetic and Plastic Surgery, Vol. 25, No. 4, 2001, pp. 286-289. doi:10.1007/s002660010138 